\title{
PENGARUH PAJAK REKLAME DAN PAJAK PENERANGAN JALAN TERHADAP PENDAPATAN ASLI DAERAH KOTA BEKASI
}

\author{
Adelina Suryati \\ Fakultas Ekonomi dan Bisnis Universitas Bhayangkara Jakarta Raya \\ Jl. Raya Perjuangan Bekasi Utara \\ Handphone: 087883681043. Email: adelina.suryati@ubharajaya.ac.id
}

\begin{abstract}
This study aims to determine whether there is an effect of the Advertising Tax and Street Lighting Tax on the Bekasi City Original Revenue during the period from 2015 to 2020. The sample selection in this study used the purposive sampling method with predetermined criteria obtained for 5 years so that the total sample used is 72 data. The type of data used is secondary data obtained from the Dispenda (Regional Revenue Service). The results of this study indicate that the Advertising Tax has a positive and significant effect on Regional Original Income with a significant level of 0.000, stating that the H1 hypothesis is accepted. Street Lighting Tax has a positive and significant effect on Regional Original Revenue with a significant level of 0.002, stating that the hypothesis H 2 is accepted. Advertising tax and street lighting tax together have a significant and significant impact on local revenue.
\end{abstract}

Keywords: Advertising Tax, Street Lighting Tax, PAD

\section{PENDAHULUAN}

Pajak adalah salah satu sumber pendapatan negara yang berfungsi sebagai sumber dana bagi pemerintah untuk membiayai pengeluaran-pengeluarannya dan pajak pula sebagai alat untuk mengatur dan melaksanakan kebijaksanaan pemerintah dalam bidang sosial ekonomi. Berdasarkan Undang-Undang Republik Indonesia Nomor 28 Tahun 2009 Tentang Pajak Daerah Dan Retribusi Daerah, pengertian Pajak Daerah, yang selanjutnya disebut Pajak, adalah kontribusi wajib kepada Daerah yang terutang oleh orang pribadi atau badan yang bersifat memaksa berdasarkan UndangUndang, dengan tidak mendapatkan imbalan secara langsung dan digunakan untuk keperluan Daerah bagi sebesarbesarnya kemakmuran rakyat.

Pajak daerah merupakan pajak yang dipungut oleh pemerintah daerah itu sendiri. Menurut mardiasmo (2016) pajak bagi pemerintah daerah berperan sebagai sumber pendapatan (budgetary function) yang utama dan sebagai alat pengatur (regulatory function), yang digunakan untuk membiayai pengeluaran Pemerintah. Dengan pelaksanaan otonomi daerah, Pemerintah Daerah harus mampu mengatur dan memiliki kewenangan yang besar untuk mengurus pemerintahan daerah secara mandiri. Berdasarkan undang-undang nomor 23 tahun 2014 tentang pemerintahan daerah, menjelaskan bahwa pemerintah daerah dapat mempercepat terwujudnya kesejahteraan masyarakat melalui peningkatan pelayanan, pemberdayaan, dan peran masyarakat, serta peningkatan daya saing daerah berdasarkan asas desentralisasi, yaitu penyerahan wewenang pemerintahan oleh pemerintah kepada daerah otonom untuk mengatur dan mengurus urusan pemerintahan dalam sistem Negara Kesatuan Republik Indonesia. Adanya otonomi diharapkan daerah dapat berkembang dalam mengembangkan potensi yang ada di daerah tersebut dapat maju dari sumber Pendapatan Asli Daerah (PAD), Devi (2016). Potensi sumber pendapatan daerah yang dapat meningkat pendapatan asli daerah (PAD) adalah dari sektor pajak daerah dan retribusi daerah (Putri, 2019).

Kota Bekasi mempunyai potensi Pendapatan Daerah yang mungkin untuk 
terus ditingkatkan setiap tahunnya sebagai penerimaan Pendapatan Asli Daerah (PAD) dari sektor Pajak Reklame dan Pajak Penerangan Jalan (PPJ). Sehubungan dengan pesatnya perkembangan Kota Bekasi dari tahun ke tahun, yaitu dengan adanya Sumarecon Bekasi sehingga pusat perbelanjaan Mall Sumarecon, Perumahan Sumarecon, Apartemen, Pasan Tradisional Sinpasa, Rumah makan mang engking, Hotel Haris, hotel Aston dan tempat hiburan lainya, serta outlet-outlet makanan. Dimana secara tidak langsung hal ini akan meningkatkan penerimaan pajak daerah dari sektor penerimaan pajak reklame dan pajak penerangan jalan (Kumala, 2019). Pajak reklame dikenakan dengan alasan bahwa reklame digunakan untuk memperkenalkan, menganjurkan atau memuji suatu barang, atau jasa yang ditempatkan ditempat yang dapat dilihat orang, dibaca, di dengar dari suatu tempat umum. Tetapi juga disebabkan sifat pajak reklame sebagai pajak objektif yang dasar pengenaannya adalah nilai sewa reklame (NSR) NSR diperhatikan dengan memperhatikan lokasi penempatan, jenis reklame, jangka waktu penyelengaraan, dan ukuran media reklame. Pajak reklame itu sendiri merupakan pajak daerah yang memiliki andil dalam salah satu pajak yang masuk dalam kas pemerintah daerah.

Tabel 1. Target Pajak Reklame \& Penerangan Jalan

\begin{tabular}{|c|c|c|}
\hline Thn & $\begin{array}{c}\text { Target APBD Paiak } \\
\text { Reklame }\end{array}$ & $\begin{array}{c}\text { Target APBD Pajak } \\
\text { Penerangan Jalan }\end{array}$ \\
\hline 2015 & 56.169 .719 .600 .00 & 230.792 .312 .545 .00 \\
\hline 2016 & 79.403 .663 .550 .00 & 294.903 .525 .300 .00 \\
\hline 2017 & 117.669 .364 .900 .00 & 380.628 .089 .000 .00 \\
\hline 2018 & 90.822 .004 .200 .00 & 415.007 .955 .600 .00 \\
\hline 2019 & 131.950 .805 .880 .00 & 493.191 .131 .096 .00 \\
\hline 2020 & 46.700 .000 .000 .00 & 350.000 .000 .000 .00 \\
\hline
\end{tabular}

Sumber: PAD Kota Bekasi
Pemerintah daerah Kota Bekasi dalam mendukung penerimaan melalui pajak reklame dan penerangan jalan tersebut menerbitkan peraturaan daerah Kota Bekasi No 14 Tahun 2014, dan peraturan daerah Kota Bekasi No 13 Tahun 2012. Selain itu, Kota Bekasi dari sudut pandang geografis terletak sangat strategis sebagai penyangga ibu Kota Jakarta dan juga sebagai jalur lintas perdagangan antar kota. Kota Bekasi juga memiliki wilayah yang cukup luas dan jumlah penduduk yang semakin meningkat jumlahnya. Berdasarkan hasil penelitian Aulia dkk, 2018 pajak reklame dari tahun 2011-2015 belum memenuhi target yang telah di tetapkan sehingga penerimaan pajak daerah terutama pajak reklame belum optimal. Pajak Reklame dalam UU No. 28 Tahun 2009 tentang pajak reklame. Pajak reklame adalah pajak atas penyelenggaraan reklame. Subjek pajak reklame adalah orang pribadi atau badan yang menyelenggarakan reklame. Pajak penerangan jalan adalah pungutan daerah atas penggunaan tenaga listrik. Perusahaan listrik yang disingkat dengan PLN PT. Persero perusahaan listrik negara. Perusahaan bukan PLN adalah perusahaan perseorangan dan/atau badan yang mengoperasikan pembangkit tenaga listrik untuk keperluan sendiri dan/atau dijual kepada pihak lain yang membutuhkan. Penelitian ini bertujuan untuk mengetahui bagaimanakah pengaruh pajak reklame dan penerangan jalan terhadap pendapatan asli daerah Kota Bekasi dari tahun 2015 sampai dengan tahun 2020.

\section{LANDASAN TEORI}

\section{Pengertian Pajak Reklame}

Menurut Undang-Undang Republik Indonesia Nomor 28 Tahun 2009 tentang Pajak Daerah dan Retribusi Daerah dan Peraturan Walikota Surabaya Nomor 70 tahun 2010 Tentang Perhitungan Nilai Sewa 
Reklame, yang dimaksud Pajak Reklame adalah pajak atas penyelenggaraan reklame. Dan yang dimaksud dengan reklame yaitu benda, alat perbuatan, atau media yang bentuk dan corak ragamnya dirancang untuk tujuan komersial memperkenalkan, menganjurkan, mempromosikan, atau untuk menarik perhatian umum terhadap barang, jasa, otang atau badan, yang dapat dilihat, dibaca, didengar, dirasakan, Dan atau dinikmati oleh umum. Dasar hukum pajak reklame adalah Nilai Sewa Reklame.

Menurut Groothuis (Maulana Aris, Cut Rizki, 2020) Pajak reklame adalah pajak wilayah yang kepentingan serta penerimaannya dipakai dan diserahkan terhadap keperluan pemerintah daerah. Biaya iklan berlaku untuk tujuan pajak, seperti papan iklan dan nilai tagihan, dan didasarkan pada jumlah biaya pemasangan papan reklame, jumlah saran biaya perawatan papan, durasi pemasangannya, nilai strategis pajak reklame. pemasangan panel dan jenis pajak reklame.

\section{Pengertian Pajak Penerangan Jalan}

Menurut (Kementerian Kesehatan Republik Indonesia, 2016) Pajak Penerangan Jalan (PPJ) adalah pajak atas penggunaan tenaga listrik, baik yang dihasilkan sendiri maupun diperoleh dari sumber lain. Penerangan jalan adalah penggunaan tenaga listrik untuk menerangi jalan umum yang rekeningnya dibayar oleh pemerintah daerah.

Menurut keputusan Menteri Dalam Negeri (Studi, 2019) pajak penerangan jalan adalah pajak atas penggunaan tenaga listrik dengan ketentuan bahwa di wilayah daerah tersebut tersedia penerangan jalan, yang rekeningnya dibayar oleh Pemerintah Daerah.

\section{Pendapatan Asli Daerah}

Menurut Cindy Y. Wenur (Hebimisa et al., 2017) mengemukakan bahwa Pendapatan Asli Daerah (PAD) merupakan pendapatan yang diperoleh pemerintah daerah atas pelaksanaan kegiatan pemerintahan dan pelayanan kepada masyarakat, serta pemanfaatan sumber daya yang dimiliki oleh pemerintah daerah. Menurut Markus Stenny Sarunda (Hebimisa et al., 2017) Pendapatan Asli Daerah (PAD) yaitu penerimaan yang diperoleh daerah dari sumber-sumber dalam wilayahnya sendiri yang dipungut berdasarkan peraturan daerah seseuai dengan peraturan perundang-undang yang berlaku. Sedangkan menurut Yani (Kementerian Kesehatan Republik Indonesia, 2016) Pendapatan asli daerah merupakan suatu pendapatan yang menunjukkan suatu kemampuan daerah menghimpun sumber-sumber dana untuk membiayai kegiatan rutin maupun pembangunan suatu daerah. PAD adalah pendapatan yang diperoleh daerah yang dipungut berdasarkan peraturan daerah sesuai dengan peraturan perundangundangan.

Menurut Raharjo Adisasmita dalam buku Pengelolaan Pendapatan dan anggaran Daerah (2011) Pajak Daerah adalah kewajiban penduduk masyarakat menyerahkan sebagian dari kekayaan kepada daerah disebabkan suatu keadaan, kejadian atau perbuatan yang memberikan kedudukan tertentu, tetapi bukan sebagai suatu sanksi atau hukum. Menurut Siahaan dalam bukunya Pajak Daerah dan Retribusi Daerah (2010) Pajak daerah adalah iuran wajib yang dilakukan oleh daerah kepada orang pribadi atau badan tanpa imbalan langsung yang seimbang, yang dapat dipaksakan berdasarkan peraturan perundang- undangan yang berlaku, yang digunakan untuk membiayai penyelenggaraaan pemerintah daerah dan pembangunan daerah. Menurut 
Darwin dalam bukunya pajak daerah dan retribusi daerah (2010) Pajak daerah adalah pajak yang dipungut oleh daerah berdasarkan peraturan pajak yang ditetapkan oleh daerah untuk kepentingan pembiayaan rumah tangga sebagai bahan hukum publik.

\section{METODE PENELITIAN}

Desain penelitian adalah rancangan penelitian yang digunakan sebagai pedoman dalam proses penelitian. Berdasarkan jenis data yang digunakan, penelitian ini merupakan penelitian kuantitatif karena menggunakan data berupa angka-angka. Berdasarkan karakteristik masalahnya, penelitian dikelompokkan dalam penelitian kausatif. Penelitian kausatif adalah penelitian yang bertujuan untuk mengetahui hubungan sebab akibat antar variabel melalui pengujian hipotesis. Jenis penelitian yang digunakan adalah studi empiris. Penelitian ini menggunakan data sekunder yang diperoleh dari dokumentasi. Penelitian dilakukan dengan menggunakan data laporan tahunan instansi Bappenda Kota Bekasi selama periode tahun 2015 sampai dengan 2020.

Sumber data yang digunakan dalam penelitian ini adalah data primer yang didapat peneliti melalui wawancara langsung dengan salah satu pihak Badan Pendapatan Asli Daerah Kota Bekasi dan data sekunder berupa data laporan target dan realisasi penerimaan pajak reklame, pajak penerangan jalan dan pendapatan asli daerah Kota Bekasi mulai tahun 2015-2020 yang di dapat dari Dinas Pendapatan Daerah (Bapenda) Kota Bekasi. Teknik pengumpulan data dalam penelitian ini menggunakan beberapa teknik untuk mendapatkan data mengenai objek yang akan diteliti, diantaranya adalah observasi, wawancara,dan dokumentasi. Dalam penelitian ini menggunakan metode analisis data berupa metode deskriptif kuantitatif dengan data sekunder, yang dilakukan untuk mengukur penerimaan pajak rekalme dan pajak penerangan jalan.

Variabel yang digunakan dalam penelitian adalah pajak reklame, pajak penerangan jalan dan pendapatan asli daerah. Pengukuran variabel pajak reklame yaitu perbandingan antara realisasi penerimaan pajak reklame dengan target pajak reklame, perbandingan antara pajak penerangan jalan, yaitu realisasi penerimaan pajak penerangan jalan dibagi target pajak penerangan jalan.

\section{HASIL PENELITIAN DAN PEMBAHASAN}

Hasil penelitian ini berkaitan dengan target yang menjadi acuan dalam memungut pajak, target berkaitan dengan tujuan yang ditetapkan oleh pemerintah untuk dicapai. Dengan mengetahui tujuan tersebut, maka akan lebih mudah untuk menentukan target yang tentunya akan berdampak pada realisasi yang tidak jauh dari perkiraan target. Hal ini berarti sebagai ukuran keberhasilan atau kegagalan dalam realisasi penerimaan pajak reklame dan pajak penerangan jalan dalam mencapai tujuan yang sebenarnya akan dicapai pada periode tertentu.

Tabel 2. Target dan Realisasi Pajak Reklame

\begin{tabular}{|c|c|c|c|}
\hline Thn & Target & Realisasi & Persentase \\
\hline 2015 & 230.792 .312 .545 .00 & 237.095 .526 .249 .00 & 102,73 \\
\hline 2016 & 294.903 .525 .300 .00 & 247.424 .896 .825 .00 & 83,90 \\
\hline 2017 & 380.628 .089 .000 .00 & 272.038 .292 .762 .00 & 71,47 \\
\hline 2018 & 415.007 .955 .600 .00 & 289.873 .023 .638 .00 & 69,85 \\
\hline 2019 & 493.191 .131 .096 .00 & 311.795 .506 .420 .00 & 63,22 \\
\hline 2020 & 350.000 .000 .000 .00 & 352.436 .804 .465 .00 & 100,70 \\
\hline
\end{tabular}

Dari tabel 2 di atas, dapat dilihat bahwa pada tahun 2020 pajak reklame mencapai target yang telah ditetapkan bahkan sampai melebihi target, tetapi pada tahun 2015-2019 realisasi pajak reklame kota Bekasi tidak 
dapat mencapai target yang telah ditetapkan, tetapi. Hal ini disebabkan beberapa faktor:

1. Wajib pajak banyak yang mangkir pada saat melakukan pembayaran pajak reklame, hal ini disebabkan karena kurangnya integrasi antara pemerintah daerah dengan pengurus jasa pajak reklame dalam hal penagihan pajaknya.

2. Dalam pelaksanaan proses perizinan dan perpanjangan pajak reklame terlalu lama, seperti lamanya proses pembuatan SKPD yang memakan waktu lebih dari 7 (tujuh) hari dan dengan hal ini akan menyebabkan pendapatan dari pajak reklame akan mengalami pengurangan sehingga untuk penyetoran dari pendapatan tersebut juga akan mengalami pengurangan akhirnya pemungutan untuk pajak reklamenya akan mengalami penurunan juga

Tabel 3. Target dan Realisasi Pajak Penerangan Jalan

\begin{tabular}{|c|c|c|c|}
\hline Thn & Target & Realisasi & Persentase \\
\hline 2015 & 230.792 .312 .545 .00 & 237.095 .526 .249 .00 & 102,73 \\
\hline 2016 & 294.903 .525 .300 .00 & 247.424 .896 .825 .00 & 83,90 \\
\hline 2017 & 380.628 .089 .000 .00 & 272.038 .292 .762 .00 & 71,47 \\
\hline 2018 & 415.007 .955 .600 .00 & 289.873 .023 .638 .00 & 69,85 \\
\hline 2019 & 493.191 .131 .096 .00 & 311.795 .506 .420 .00 & 63,22 \\
\hline 2020 & 350.000 .000 .000 .00 & 352.436 .804 .465 .00 & 100,70 \\
\hline
\end{tabular}

Dari tabel 3 di atas, dapat dilihat bahwa pada tahun 2015 dan tahun 2020 mencapai target. Kemudian pada tahun 2016 sampai dengan tahun 2019 tidak mencapai target.

Tabel 4. R Square

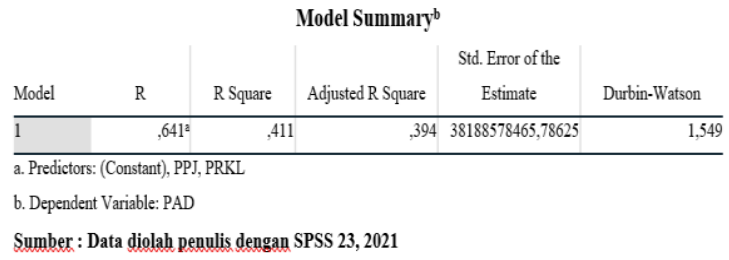

Berdasarkan tabel 4, diperoleh nilai koefisien determinasi yang ditunjukkan dalam kolom Adjusted $R$ Square sebesar 0,411 yang menunjukkan bahwa variabel independen yang dipengaruhi variabel dependen sebesar 41,1\%. Artinya ada pengaruh antara variabel pajak reklame dan pajak penerangan jalan terhadap pendpatan asli daerah sebesar $41,1 \%$ sedangkan sisanya dipengaruhi oleh variabel lain yang belum diteliti dalam penelitian ini.

Tabel 5. Uji t

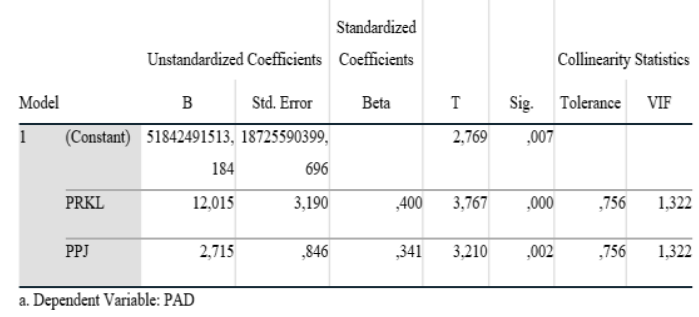

Sumber: Data diolah penulis dengan SPSS, 2021

Pada tabel 5 diperoleh nilai $t_{\text {hitung }}$ variabel pajak reklame (PRKL) adalah sebesar 3,767 dengan $t_{\text {tabel }} 1,993$. Dilihat dari nilai pair value sebesar 0,000 lebih kecil dari 0,05 . Sedangkan $t_{\text {hitung }} 3,767$ lebih besar dari $t_{\text {tabel }} 1,993$ artinya terdapat pengaruh positif antara pajak reklame terhadap pendapatan asli daerah Kota Bekasi periode tahun 2015 sampai dengan 2020. Pajak penerangan jalan (PPJ) diperoleh nilai thitung sebesar 3,210 dengan $t_{\text {tabel }}$ 1,993. Dilihat dari nilai pair value sebesar 0,002 lebih kecil dari 0,05. Artinya terdapat pengaruh positif antara pajak penerangan jalan terhadap pendapatan asli daerah Kota Bekasi tahun 2015 sampai dengan tahun 2020.

Tabel 6. Uji F

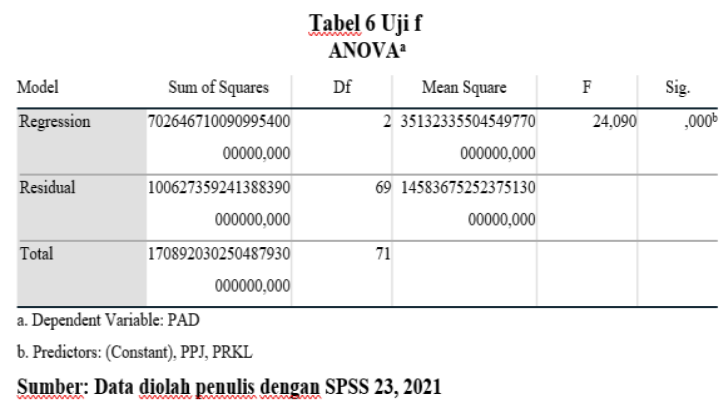


Berdasarkan hasil uji secara bersama-sama dengan nilai pair value sebesar 0.000, hal ini menggambarkan bahwa pajak reklame dan pajak penerangan jalan berpengaruh positif dan signifikan pada pendapatan daerah Kota Bekasi.

\section{Pembahasan}

\section{Pengaruh Pajak Reklame terhadap Pendapatan Asli Daerah}

Berdasarkan hasil uji statistic bahwa pajak reklame sangat berpengaruh terhadap pendapatan asli daerah Kota Bekasi karena dengan berkembangnya pusat-pusat sentra bisnis dan kuliner di Kota Bekasi, bertambahnya Mall, rumah mewah, apartemen, hotel, dan tempat makan Seribu Rasa. MC Donald, Solaria, Richeesse, salonsalon kecantikan,dan boutique. Untuk memasarkan produk tersebut diatas menggunakan banyak memasang reklame yang besar di sepanjang jalan Raya Kota Bekasi, sehingga peningkatan pendapatan reklame semakin meningkat walaupun dalam kondisi Covid-19. Masyarakat Kota Bekasi adalah masyarakanya konsumtif karena kebanyakan dari masyarakat Kota Bekasi pendatang atau bukan asli bekasi.

Hasil penelitian tidak sejalan dengan penelitian Wulan Purnama Sari dan Zainur Ihsan (2020) yang menyatakan bahwa Pajak reklame tidak berpengaruh terhadap Pendapatan Asli Daerah. Pajak merupakan salah satu sumber penerimaan pemerintah untuk membiayai pengeluaran pemerintahan baik rutin maupun pembangunan. Badan Pengelola Pendapatan Daerah Kabupaten Sintang dibentuk berdasarkan Peraturan Bupati Sintang Nomor 131 Tahun 2016 Tentang Susunan Organisasi dan Tata Kerja Badan Pengelola Pendapatan Daerah Kab. Sintang. Berdasarkan Peraturan Bupati Sintang tersebut, BAPPENDA merupakan unsur pelaksana teknis pemerintahan daerah yang dipimpin oleh Kepala Badan yang berada dibawah dan pertanggung jawab kepada Bupati melalui Sekretaris Daerah sesuai dengan bidang kewenangannya. Sumber pendanaan pelaksanaan pemerintahan daerah di Kab. Sintang terdiri dari Pendapatan Asli Daerah, Dana Perimbangan, Hasil Pengelolaan Kekayaan Daerah Yang Dipisahkan dan Pendapatan Lain-lain yang sah.

\section{Pengaruh Pajak Penerangan Jalan terhadap Pendapatan Asli Daerah}

Berdasarkan hasil uji statistik menyatakan bahwa pajak penerangan jalan berpengaruh terhadap pendapatan asli daerah Kota Bekasi. Berkembangnya Kota Bekasi sangat di pengaruhi dengan berkembangnya teknologi terutama di penerangan jalan. Dengan perkembangan Kota Bekasi yang sudah sentra bisnis dan kuliner serata hotel seluruh jalan jalan di Kota Bekasi harus terang.

Hasil penelitian sejalan dengan penelitian Dewi Sartika, Suci Ramadhani dan Andre Ilyas (2020) yang menyatakan bahwa Pajak Reklame berpengaruh terhadap Pendapatan Asli Daerah. Penerangan jalan adalah penggunaan tenaga listrik untuk menerangi jalan umum yang rekeningnya dibayar oleh Pemerintah Daerah. Sehinnga penerimaan pajak yang diperoleh dari pajak penerangan jalan akan digunakan untuk membiayai penerangan jalan pada jalan umum meliputi pemeliharaan dan perbaikan lampu jalan.

\section{KESIMPULAN DAN SARAN}

\section{Kesimpulan}

$\begin{array}{cccc}\text { Berdasarkan } & \text { penelitian } & \text { yang } \\ \text { dilakukan mengenai } & \text { pengaruh } & \text { Pajak } \\ \text { Reklame Dan Pajak } & \text { Penerangan } & \text { Jalan }\end{array}$


Terhadap Pendapatan Asli Daerah Kota Bekasi, maka dapat diambil kesimpulan sebagai berikut:

1. Terdapat pengaruh positif dan signifikan antara Pajak Reklame terhadap Pendapatan Asli Daerah Kota Bekasi periode tahun 2015 sampai dengan tahun 2020.

2. Terdapat pengaruh positif dan signifikan Pajak Penerangan Jalan terhadap Pendapatan Asli Daerah Kota Bekasi periode tahun 2015 sampai dengan tahun 2020.

3. Terdapat pengaruh secara simultan dari Pajak Reklame Dan Pajak Penerangan Jalan Terhadap Pendapatan Asli Daerah kota Bekasi periode 2015-2020.

\section{Saran}

Berdasarkan hasil analisis dan pembahasan serta kesimpulan yang telah diuraikan, adapun saran yang dapat diberikan melalui hasil penelitian ini adalah sebagai berikut:

1. Untuk Bapenda Kota Bekasi agar meningkatkan Pendapatan Daerah Kota Bekasi harus sudah menggunakan teknologi informasi digital dan secara online.

2. Prosedur pengurusan dan Perpanjangan Pajak Reklame dan Penerangan Jalan di Kota Bekasi agar tidak terlalu lama dilakukan juga secara digital dan online untuk menghindari antri, dan data terselip/hilang di petugas.

\section{DAFTAR PUSTAKA}

Adi, R. H. W., Tinangon, J. J., \& Elim, I. (2020). Evaluasi Efektivitas Penerimaan Pajak Hotel, Pajak Reklame, Pajak Hiburan Dan Kontribusi Di Pemerintah Kota Manado. Jurnal Emba: Jurnal Riset
Printed ISSN : 2406-7415 Elektronik ISSN : 2655-9919 Jurnal Akuntansi dan Bisnis Krisnadwipayana Volume 9 Nomor 1 (Januari - April) 2022

Ekonomi, Manajemen, Bisnis Dan Akuntansi, 8(4).

Ariyanti, R., Setiawan, S., \& Cahyati, N. (2020). Analisis Efektivitas Dan Kontribusi Penerimaan Pajak Reklame Terhadap Pendapatan Asli Daerah Kabupaten Pekalongan. Balance: Economic, Business, Management And Accounting Journal, 17(1), 49-56.

Cahyono, C., \& Agustina, P. A. (2020). Analisis Potensi Dan Efektivitas Penerimaan Pajak Reklame Di Kabupaten Sumedang. Sintesa Stie Sebelas April Sumedang, 10(2), 66-67. Ichsan, A., Siregar, H., \& Soetarto, E. (2018). Strategi Pemungutan Penerimaan Pajak Reklame Kota Bekasi. Jurnal Manajemen Pembangunan Daerah, 10.

Kumala, R. (2019). Analisis Efektifitas Pajak Reklame Dalam Meningkatkan Penerimaan Pajak Daerah Di Kota Bekasi. Jurnal Reformasi Administrasi: Jurnal Ilmiah Untuk Mewujudkan Masyarakat Madani, 6(1), 38-41.

Kurniasari, A. M., Widhianningrum, P., \& Sulistyowati, N. W. (2017, October). Analisis Efektivitas Dan Kontribusi Pajak Reklame Dalam Meningkatkan Pendapatan Asli Daerah Kota Madiun. In FIPA: Forum Ilmiah Pendidikan Akuntansi (Vol. 5, No. 1).

Madina, R. I. (2015). Faktor-Faktor Yang Mempengaruhi Implementasi Regulasi Daerah Terkait Penerimaan Pajak Reklame (Studi Kasus Di Dinas Pendapatan Daerah Kota Malang). Jurnal Mahasiswa Perpajakan, 6(2).

Maulana, A., Rizki, C. Z., Varlitya, C. R., \& Miksalmina, M. (2020). Analisis Pengaruh Jumlah Penduduk, Jumlah Industri Dan Pdrb Terhadap Penerimaan Pajak Reklame. Jurnal 
Ilmiah Mahasiswa Ekonomi

Pembangunan, 5(1), 1-9.

Rinawati, R. (2013). Analisis Pengaruh

Pemungutan Pajak Reklame Terhadap Upaya Peningkatan Pendapatan Asli Daerah (PAD) Kota Surabaya. Jurnal Akuntansi AKUNESA, 1(2).

Sari, W. P., \& Ihsan, Z. (2020). Laju Pertumbuhan Pajak Hotel, Pajak Restoran, Pajak Reklame Dan Pajak Penerangan Jalan Dalam PAD Kabupaten Sintang. Jurnal Produktivitas: Jurnal Fakultas Ekonomi Universitas Muhammadiyah Pontianak, 7(2).

Sartika, D., Ramadhani, S., \& Ilyas, A. (2020). Analisis Efektivitas Pajak Penerangan Jalan Dan Kontribusinya Terhadap Pendapatan Asli Daerah Di Kota Padang Tahun 2013-2017. Jurnal Ekonomi Dan Bisnis Dharma Andalas, 22(1), 22-31.

Tamburaka, S., Husin, H., \& Dwiatmojo, M. A. "Pengaruh Pajak Penerangan Jalan Terhadap Penerimaan Pendapatan Asli Daerah"(Studi Pada Kabupaten/Kota Se Provinsi Sulawesi Tenggara). Jurnal Akuntansi Dan Keuangan, 5(2). 